\title{
Chapter 7 \\ Reinhold Niebuhr During the Time of the White Compromise
}

\subsection{Introduction}

The Reconstruction era ended with the "white compromise" of 1876 when Northern and Southern politicians agreed to let Rutherford B Hayes become President and to withdraw Federal troops form the former Confederate states. The compromise allowed white Southerners to "redeem" the South from Black citizens and to institute a Jim Crow regime that continued to dominate the South until the 1950s. The four strands of American prosperity-commercializing of land, racializing humanity, incoherent social relationships, and the militarization of the civic continued without limits. This expansion was not without its critics, even white male critics. Foremost among them was the theological ethicist Reinhold Niebuhr. Even though Niebuhr did not address all four strands of American prosperity, his work on setting limits does offer us important lessons for what white males and others could do and not do today.

Reinhold Niebuhr's most influential time was in the 1940s and 1950s. As co-founder of the Americans for Democratic Action, he and his cohorts determined much of American foreign policy. Time magazine featured his picture on its 1948 cover. In 1964, Niebuhr received the Presidential Medal of Freedom, the highest recognition given to civilians in the United States.

We have recently seen a revival of interest in Niebuhr's life and work. In 2017, the Public Broadcasting Corporation presented a Reinhold Niebuhr documentary, "An American Conscience: The Reinhold Niebuhr Story" (PBS 2017), They may have been inspired, at least in part, by President Barak Obama naming Reinhold Niebuhr his favorite philosopher. In a 2007 opinion piece on President Obama in the New York Times, the columnist David Brooks shares what Obama said he had learned from Niebuhr: 
The compelling idea that there's serious evil in the world, and hardship and pain. And we should be humble and modest in our belief we can eliminate those things. But we shouldn't use that as an excuse for cynicism and inaction. I take away ... the sense we have to make these efforts knowing they are hard, and not swinging from naïve idealism to bitter realism (2007).

I think President Obama is talking about a balance here between idealism and realism, a balance that certainly belongs to a climate of justice.

Niebuhr's reputation largely derives from his idea of Christian Realism, which highlighted the complexity of doing good or even being good, especially for groups and nations. Instead of aiming for some idealistic resolution of national conflicts, Niebuhr believed that the aim should be their containment. He was aware, in other words, of the limits that must be placed on some parts of American prosperity namely, its militarized civic. His development of this notion of limits, its relationship with the other strands of American prosperity, and its impact on the national climate of injustice are the topics of this chapter.

Growing up in Nebraska in the 1950s, I took for granted the construction of white male supremacy as normal until my time at Nebraska Wesleyan University when I began hearing of the voter registration efforts and the freedom rides in the segregated south. When I joined others in 1965 walking down the streets of Montgomery, Alabama to hear Martin Luther King Jr. speak at the State Capital, I knew the times "they were a changing." Later that year I began my studies at Union Theological Seminary in New York, and in 1966 I took a graduate seminar on Reinhold Niebuhr's thought with Dr. Beverly Wildung Harrison, who later became a leading scholar in feminist ethics (2004). At the end of the semester, we were invited to a meeting with Niebuhr who had retired, but still lived at Union. He graciously answered our questions about his two-volume book, The Nature and Destiny of Man (1941). In this work, Niebuhr provides the theological and Biblical grounding of his belief in the fundamental ambiguity of human existence (Fig. 7.1).

\subsection{Niebuhr's View of the Ambiguity of Human Existence}

So where is the ambiguity? Is it living in a world where we are destroying the Earth's capacity to provide for us? Or, declaring that we welcome "the huddled masses yearning to breathe free"; yet putting immigrant families in detention camps? One thing seems certain: for Niebuhr American life was ambiguous. He grappled with the race issue more than many other whites during his lifetime, and certainly was aware of the difficulty of dealing with white privilege, as well as social change. In his most famous book, Moral Man and Immoral Society, Niebuhr gives advice that has particular relevance for our efforts in creating a climate of justice:

The ability to consider, or even to prefer, the interests of others to our own, is not dependent upon the capacity for sympathy. Harmonious social relations depend upon a sense of justice as much as, or even more than, upon the sentiment of benevolence. This sense of justice is a product of the mind and not the heart. It is the result of reason's insistence upon consistency (1960, p. 29). 


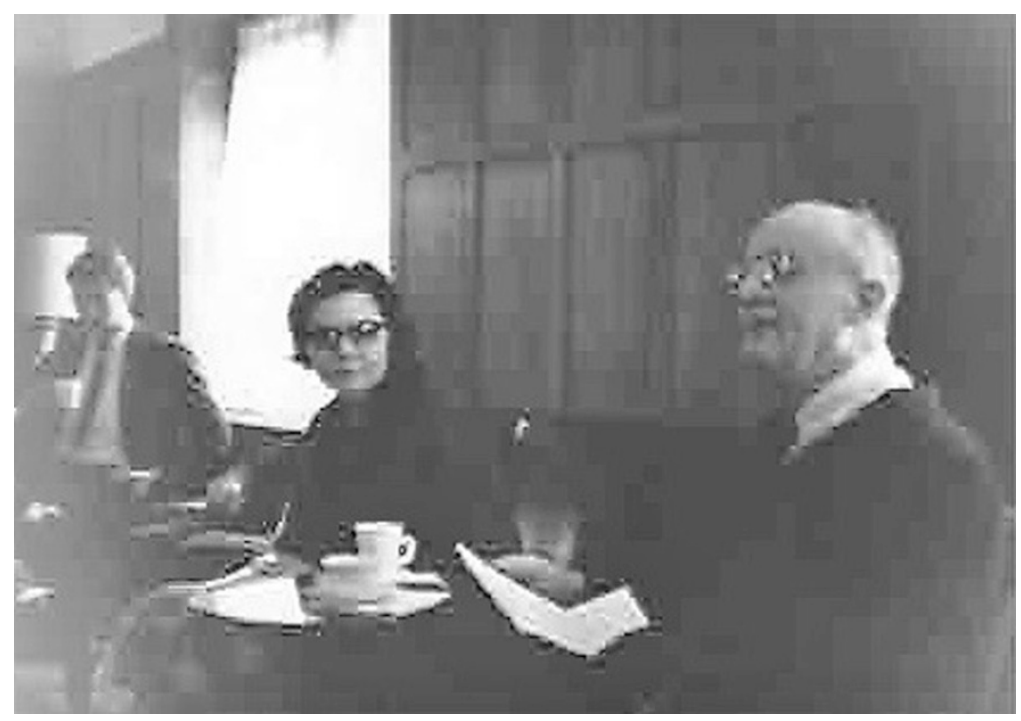

Fig. 7.1 Photo with Reinhold Niebuhr and Beverly Wildung Harrison (Original to the author)

I hear something quite like "a climate of justice in Niebuhr's phrase "a sense of justice," and I agree with him that sympathy alone is not sufficient. On the other hand, a sense of justice is a product of both the mind and the heart, to use his metaphors. In other words, I would not say what he said quite in the same way; and yet, I would not say what I do say without having heard what he said. He raises the questions, and, if we feel the answers are not complete or quite accurate, we are, at least, looking at the questions. If we are to correct the injustice of the white compromise and create a new climate of justice, I know of no better way to discover what that requires than to listen to what Niebuhr said and then to figure out what we should say now.

So, where did Niebuhr learn this view of the limited human capacity for change during the time of the white compromise? My assumption behind this question is that learning involves a circular process between experience and ideas. Our ideas give us a particular reading of our experiences, and these experiences influence our understanding of our ideas. At the same time, this learning process occurs in what are largely taken-for-granted social worlds. In what follows, I will describe some of the highlights of Niebuhr's experiences and ideas, and make a plausible interpretation, I hope, of their meaning in the time of the white compromise. The purpose is not to dismiss Niebuhr's ideas, but rather to gain a better understanding of how to build on them and of what we must do differently if we want to move toward a climate of justice not just for our social relations but also for our relations with the Earth.

The white compromises, from the compromise to count enslaved people as $3 / 5$ ths of a person to the compromise that allowed white Southerners to "redeem" the South following the demise of Reconstruction, held white America together and forced 
others to submit. These compromises allowed white people to understand their good fortune as though people of color did not exist. This was not true for Reinhold Niebuhr. He was quite involved at different times in the "negro problem." At the same time, there were traumatic events for black people that Niebuhr appears to ignore. The story about his relationship with issues of race is fairly complex and requires some discernment. We begin with a few of the many episodes of racial conflict in the early twentieth century that were excluded from the American story I had been told, and yet these episodes belong to any truthful recording of the American experience: the urban race riots, the second rise of the KKK, the Elaine massacre in 1919, and attempts to pass legislation against lynching.

\subsection{Racial Conflict During the Time of the White Compromise}

Cameron McWhirter calls the summer of 1919 the "red summer," because it was a summer on fire with race riots (2011). The confluence of the migration of Blacks moving North, the rise of the KKK, the battles between labor unions and owners, the socialist revolution in Russia, and soldiers returning from WWI all made for racial explosions in many urban centers, including Charleston, Chicago, Cleveland, Austin, Knoxville and Omaha. By reviewing various records, McWhirter writes, "at least 25 major riots and mob actions erupted and at least 52 black people were lynched" (p. 15). Most of these riots were in Northern cities where Black migration from the south had changed the demographics.

At the beginning of the twentieth century, most Blacks lived in the south. There were black professionals and activists in the North, such as W.E.B. Du Bois in Boston, and in the Caribbean, such as Edmond Blyden, Markus Garvey, and John Henrik Clarke, who are noted for advocating that Blacks should return to Africa. In the South, besides a small educated and professional class including church and education leaders, most Blacks belonged to a working class of poor laborers. Many who had the means migrated to the Northern cities to find better paying work and to escape the terrorism of the Jim Crow regime. When the migration ended in the 1970s, over six million Blacks had moved to Northern and Western cities. The percentage of Blacks living outside the South had changed from 10\% to almost 50\% (Wilkerson 2011, p. 10).

In Northern cities, Blacks encountered a racial regime of segregation that kept them from settling in any other place than in what became known as "black ghettos." As Beth Tompkins Bates points out: "The black ghetto marked a new phase in residential restrictions by limiting where American citizens could live" (2014, p. 93). As the Black population grew so did the growth of the Klan.

After whites had gained control of the South in the 1870s, the Klan faded into the background, but it returned in the early twentieth century. . This second incarnation of the Klan held on to the old belief in white supremacy, but also added hatred 
toward Jews and Catholics. It was much more popular in Western and Northern urban areas than in the old south. The 1915 film, "Birth of a Nation" greatly enhanced its popularity. Originally named "The Clansman," the film portrays the Klan as a positive force protecting whites against aggressive Blacks. Although the NAACP protested its showing in several cities, it was a great success. The Klan's national popularity peaked in 1925 with around sixty thousand men marching down Pennsylvania Avenue in Washington DC. 1919 was the worst year for Blacks during this resurgence of the Klan. Perhaps the most shocking event in the "red summer" of 1919 was the Elaine massacre.

\subsubsection{The Elaine Massacre}

Elaine was a town in Phillips County, Arkansas. Phillips County was located in the Arkansas Delta, which along with the Mississippi Delta provided some of the best soil for growing cotton. Actually, the "alluvial empire," as Nan Elizabeth Woodruff names it, was forested with hardwood trees, which brought mostly Northern lumber companies to the area. In 1919, 20,000 people in Arkansas worked for lumber companies (2003, p. 17) Once the land was cleared, it became ideal for raising cotton, with sharecroppers doing most of the work. Most Blacks preferred sharecropping to working for wages because it seemed less like slavery. As Eric Foner points out:

While sharecropping did not fulfill blacks' desire for full economic autonomy, the end of
planters' coercive authority over the day-to-day lives of their tenants represented a funda-
mental shift in the balance of power in rural society, and afforded blacks a degree of control
over their time, labor, and family arrangements inconceivable under slavery (2002, p. 406).

The basic idea was that laborers would contribute their labor and the landowner would contribute the land, and when the laborer didn't have his own tools, the landowner provided them and sometimes a mule, to grow and harvest the crop. The crop was then shared, usually 50/50. Although this looked like a good deal, it didn't turn out that way. The sharecropper needed provisions for the family until the crop was harvested, which meant the family was usually in debt to the landowner. Also, they had to get family provisions on credit at company stores, so their share of the crop rarely paid off their debts. It turned out to be a kind of debt slavery.

Following the First World War, the price of cotton increased as did cotton yield, but the sharecroppers did not see their income increase, in part because they had to sell their share to the landowner rather than on the open market. The sharecroppers began to talk about improving their situation. In 1919, a sharecropper union, the Progressive Farmers and Household Union of America (PFHUA), arranged for a meeting at a church near Elaine, Arkansas. Around 200 people attended. A few whites came to the church and engaged in a gun exchange with the PFHUA guards. One white man was killed. Soon, over a hundred white men from around the area gathered at the church and began shooting. This violence escalated when federal 
troops were brought in to gain control. Over several days, white civilians and Federal troops combed the region, shooting black men, women and children-some estimates put the number of murdered in the hundreds. Other reports that seem undisputed put the number at over 200 (Woodruff 2003, p. 103).

After an investigation by an all-white committee, 122 black men and women were charged with such crimes as murder and "night riding," which was a kind of terrorism made famous by the KKK. At the first trial 12 men were sentenced to death. They became known as the "Elaine Twelve," and after lengthy legal proceedings, they were all released. The anti-lynching activist, Ida B Wells, visited Phillips County in 1920 and wrote a book on the events. Her summary focuses on the economic impact of the Elaine massacre or riot for both whites and blacks:

It means that the white lynchers of Phillips County made a cool million dollars last year off the cotton crop of the 12 men who were sentenced to death, the 75 who are in the Arkansas penitentiary and the 100 whom they lynched outright on that awful October 1, 1919! And that not one of them has ever been arrested for this wholesale conspiracy of murder, robbery and false imprisonment of these black men, nor for driving their wives and children out to suffer in rags and hunger and want (1920, p. 32).

Perhaps because no whites were held accountable for the Elaine massacre, it has been largely erased from our national story, as have attempts to stop the terroristic practice of lynching.

\subsubsection{Anti-lynching Legislation}

Between the 1880s and the 1950s, there were over 5000 lynchings (Cone 2011, p. 31) Some lynchings were large-scale public events with hundreds of whites watching the spectacle. In some cases, the victims were tortured before they were lynched and burned afterwards. It's incredible that the government allowed these crimes against humanity to continue for decades. Black activists did appeal to Congress to stop it. W.E.B. Du Bois and Ida B. Wells along with white allies, did persuade Congress to draft anti-lynching legislation. Working through such agencies as the National Association for Advancement of Colored People (NAACP), the National Association of Colored Women (NACW), and the Council for Interracial Cooperation (CIC) as well as the Association of Southern Women for the Prevention of Lynching (ASWPL) an anti-lynching bill was placed before Congress in the 1920s (Dyer Anti-Lynching Bill 1922). It passed the House of Representatives but was defeated in the Senate by Southern senators. Finally, in 2005, Congress did formally "apologize" for not passing legislation against lynching (S.Res. 39(109))

As far as I know, Reinhold Niebuhr never wrote about these events. Niebuhr's early biographer, Richard Wightman Fox never mentions the Elaine massacre or the attempts to pass anti-lynching legislation in the 1920s. Fox writes that Niebuhr didn't preach about the race issue until 1925, when the KKK supported a candidate for Detroit mayor (1996, p. 96). Fox surmises: 
His Christian prophecy was so completely rooted in his reading of the industrial conflict between skilled white workers and their employers-in his hope that the American worker could join with enlightened professional people to form a Labor Party on the British model - that it had no place for the black struggle for equality (p. 94).

At the same time, Niebuhr was involved in the organizing of sharecroppers in the 1930s, which we will review in the course of following his career from Detroit to New York and beyond. We begin with his time in Detroit.

\subsection{Niebuhr in Detroit}

Niebuhr began his career as a Lutheran pastor in Detroit, Michigan. During his time in Detroit, from 1917 to 1928 , the city changed dramatically. Due to the enormous growth of the auto industry and the jobs it provided, millions of African Americans, as well as white southerners, came to Detroit for work. In the 1920s, Detroit was the fourth largest city in the United States.

The increase of the black population in Northern cities was matched with the rise of the Ku Klux Klan. In the Fall of 1921, there were approximately 3000 Klan members in Detroit; in 1924 there were more than 22,000. If one were to look at Detroit through a pair of binoculars, one eye would see the over-crowded black ghetto, and the other eye would see the Klan's political agitation. This tension between white and black groups defined the context in which Niebuhr carried out his parish ministry. He not only witnessed this racial crisis, but also served as Chairman of an Inter-Racial Committee. In his notebook, later published with the title, Leaves from the Notebook of a Tamed Cynic, Niebuhr wrote about the misery of the black community.

It has been a rare experience to meet with these white and colored leaders and talk over our
race problems. The situation which the colored people of the city face is really a desperate
one, and no one who does not spend real time in gathering the facts can have any idea of the
misery and pain which exists among these people, recently migrated from the south and
unadjusted to our industrial civilization. Hampered both by their own inadequacies and the
hostility of a white world they have a desperate fight to keep body and soul together, to say
nothing of developing those amenities which raise life about the brute level (1957, p. 115).

Niebuhr's biographer, Fox, surmises that Niebuhr must not have seen black people as part of the industrial struggle between labor and owners, or perhaps believed they were not yet developed enough to participate. On the other hand, while Niebuhr may not have taken up the issue of racism in Detroit beyond this passing reference, he did take on the rising influence of the Ku Klux Klan. In the 1924 city election campaign, the Klan supported one of the candidates for the office of mayor, Niebuhr described the Klan as "one of the worst specific social phenomena which the religious pride of a people has ever developed" (Fox 1996, p. 91) The Klan candidate was not elected, and soon afterward Niebuhr left for New York.

Niebuhr left Detroit in 1928 for a position in Christian Ethics at Union Theological Seminary in New York City. Sherwood Eddy, a social activist with family 
money, and at that time the director of the New York YMCA, covered Niebuhr's salary during his first years in New York (p. 105). Eddy, in fact, used his family money numerous times to support various projects that involved Niebuhr. When Niebuhr arrived in New York, one might imagine that he brought with him his experiences of black and white community conversations. How could he not have? So how did these experiences influence his ideas and actions? In 1945, he wrote a short piece in the journal Christianity and Society about racial bigotry:

Race bigotry is, in short, one form of original sin. Original sin is something darker and more terrible than mere stupidity and is therefore not eradicated by enlightenment alone, though frequently enlightenment can break some of its power by robbing it of some of its instrument of stupidity. While the general predisposition is not malice, it does issue in specific attitudes which have malice in them. Racial bigotry, like every other form of human pride and sin, is something more than ignorance and something less than malice (1945, p. 233).

What are we to make of Niebuhr's idea here that racial bigotry is a form of original sin? Niebuhr appears to ignore the relationship between groups and how they co-create each other. One may certainly characterize a group as you would an individual as having particular traits, but a social perspective would see these traits as results of certain types of behavioral patterns developed over time, perhaps generations.

One characteristic of white privilege, which was taken-for-granted during the time of the white compromise, is that whites did not have to examine their relationship with Blacks? One can speak of the plight of poor Blacks, which Niebuhr certainly did, or white racism, as he also did, but he omitted speaking about the social relationship that created these different social worlds.

Another aspect of living during the white compromise for white people was that one could exclude one's self from one's analysis. Nowhere do we see Niebuhr writing about his understanding of himself as a white male. Like most academics and religious leaders during his time, and even today, Niebuhr appears to take a universal perspective from which he surveys what is going on, as though he did not have a social identity. I took a similar stance earlier in my career.

When I was working in the Ethics and Diversity Program at Levi Strauss and Company in the 1990s, I learned that a necessary step in entering into conversations with others about race and related issues was to become more aware of myself as a white male. Today, we can recognize that the movement beyond the white compromise has created a different social world than the white world of social amnesia. At the same time, we still live in a world similar to Niebuhr's, and his notion of Christian Realism continues to have its advocates.

\subsection{Niebuhr's Christian Realism}

Although Niebuhr does not draw a direct line between his experiences with individuals and groups in Detroit and his ideas about moral individuals and immoral collectives or groups, one can imagine that these experiences are related. The 
connection is easily obscured, if there is one, because of Niebuhr's flexibility in using different terminologies. In Moral Man and Immoral Society (1932), he uses the ideas of collective egoism and the notion of individual and collective impulses:

The inferiority of the morality of groups to that of individuals is due in part to the difficulty of establishing a rational social force that is powerful enough to cope with the natural impulses by which society achieves its cohesion; but in part it is nearly the revelation of a collective egoism, compounded by the egoistic impulses of individuals, which achieve a more vivid expression and a more cumulative effect when they are united in a common impulse than when they express themselves separately and discreetly (1960, p. xii).

I assume these "impulses" refer to the notion of "basic drives." In a collective, the individual impulses join together to become a group force almost impossible to control. Is this Niebuhr's interpretation of the KKK? We don't know. Niebuhr actually applies this idea of the immorality of collectives to all groups - groups promoting racism and groups against racism. This is just the nature of collectives. Group cohesion depends on some kind of "group pride," which may be restrained, but not eliminated.

If we cannot overcome the faults of group morality, as Niebuhr suggests, then maybe we should tend our own garden, so to speak, and stay away from grandiose projects. Instead of moving in this direction, however, in the 1930s, Niebuhr founded several organizations that promoted economic and racial justice. These activities do not receive a lot of attention today, but for us they illustrate an attempt to break through the silence about the Jim Crow reign in the south. Let's call this Niebuhr's Christian “idealism.”

\subsection{Niebuhr's Christian "Idealism”}

In 1931-1932, Niebuhr served as chairman of the Fellowship of Reconciliation. He left the group in 1933, because he no longer agreed with their pacifism. He joined with others in 1932 to organize the Fellowship of Socialist Christians. Niebuhr was the editor and major voice for the organization's journal, Radical Religion, which he used to spread his ideas. In 1934, he helped establish the Committee for Economic and Racial Justice. Among his many activities during these years, he became involved in the organizing of sharecroppers in Arkansas and Mississippi through the Southern Tenant Farmers' Union (STFU) and the Delta Cooperative Farm.

\subsubsection{The Southern Tenant Farmers'Union}

During the Depression, cotton farmers produced more cotton than customers could afford to buy, so the Federal Government, through the Agricultural Adjustment Administration (AAA), paid farmers to take land out of production. Since the owners received government payments for not farming all their land, the sharecroppers had 
less land to farm, which drove them deeper into poverty. As in the case that led to the Elaine meeting, the sharecroppers began to organize, only this time with the help of the Southern Tenant Farmers' Union (STFU).

The STFU was founded by white Southern radicals with socialist affiliations and included both black and white sharecroppers. One of the organizers, Howard Kester, wrote a booklet about the work of the STFU in 1936. He writes;

\footnotetext{
However well-meaning the present administration of the affairs of the Department of Agriculture may appear to the casual observer, it is a fact recognized by practically every competent economist that the actual working-out of the AAA in the cotton industry has had a calamitous and devastating effect on the masses or people, white and colored. Indeed, it is doubtful if the Civil War actually produced more human suffering and pauperized more individuals in proportion to the population than the AAA has done in its few years of existence (1997, p. 27).
}

Kester worked for Niebuhr's Committee for Economic and Racial Justice. Niebuhr wrote the following in his Forward to Kester's book:

There is no more striking irony in modern politics than the fact that the provisions of the Agricultural Adjustment Administration, designed to alleviate the condition of the American farmer, should have aggravated the lot of the poorest of our farmers, the Southern sharecroppers ("Forward," 1997).

Kester and Niebuhr, along with a few others, were also involved in the organizing of a cooperative farm for both black and white sharecroppers.

\subsubsection{The Delta Cooperative Farm}

In 1936, through the Fellowship of Christian Socialists, Niebuhr helped Sherwood Eddy, his fellow activist and philanthropist, set up a cooperative farm for sharecroppers from Arkansas and Mississippi called the "Delta Cooperative Farm." Nineteen black families and twelve white families worked the farm together and shared their productivity. In time, they built houses for all the members, a sawmill, tended a large vegetable garden, and established a school for black children, who were not permitted to go beyond 4th grade in the state schools. By 1937, the farm was receiving national attention as a successful experiment in racial justice. The reality, however, was more complicated. The farm never achieved financial independence, but always depended on donations. Also, members of the Trustees had different opinions about farm leadership. And finally, some members left for other careers. In 1942 the trustees sold the farm and the new owner kept the farm in operation for another 14 years on donations. In 1956, the farm ceased all operations.

Niebuhr never wrote about these projects. How much he was involved is difficult to know. Still, they do represent attempts to change the status quo for Blacks in the South. In contrast to his work in Detroit, as the chairman of an interracial committee, where he encouraged civic dialogue, in the South, instead of focusing on changing 
social relations among blacks and whites, he helped form an alternative group within the existing society.

Both the Southern Tenant Farmers' Union and the Delta Project assumed that human freedom entailed control over land. Land, in other words had a social meaning. This insight, however, could not be fully articulated in the language of American prosperity where land is a commodity. So, while the sharecroppers recognized there was more to land than its economic value, they did not have the language to treat it as a human habitat, and neither did Niebuhr.

At the same time, these projects to empower sharecroppers did address the issue of control over one's own work. There are many worker-owned cooperatives today that can be seen as belonging to this tradition (Alperovitz 2013). They certainly provide an alternative to the dominant model of private enterprise, but do not address the issue of how to repair past violations of our common humanity. This issue is tricky because it involves the powerless making claims on the powerful. Some activists, such as those involved in the anti-lynching campaign, did engage in such work. I don't see any evidence that Niebuhr did. He does, however, write about the use of non-violent action.

\subsection{Niebuhr on Non-violent Action}

In his analysis of the merits of non-violence, Niebuhr uses the example of Gandhi, who employed such practices to force the British government to grant independence to India. Niebuhr proposes that the success of non-violence rests on making a distinction between moral individuals and immoral society.

One of the most important results of a spiritual discipline against resentment in a social dispute is that it leads to an effort to discriminate between the evils of a social system and situation and the individuals who are involved in it. Individuals are never as immoral as the social situations in which they are involved and which they symbolize. If opposition to a system leads to personal insults of its representatives, it is always felt as an unjust accusation. William Lloyd Garrison solidified the south in support of slavery by the vehemence of his attacks against slave-owners. Many of them were, within the terms of their inherited prejudices and traditions, good men; and the violence of Mr. Garrison's attack upon them was felt by many to be an evidence of moral perversity in him. Mr. Gandhi never tires of making a distinction between individual Englishmen and the system of imperialism which they maintain (1960, pp. 248-249).

Niebuhr proposes that the Negro community take a similar approach of non-violent resistance. Even though educational efforts may help a few, he writes:

However large the number of individual white men who do and who will identify themselves completely with the Negro cause, the white race in American will not admit the Negro to equal rights if it is not forced to do so. Upon this point one may speak with a dogmatism which all history justifies (p. 253). 
For Niebuhr, racism and discrimination is not an individual problem, but a social problem, and social problems are not easy to solve. He seems to advocate non-violent action not only because it has the best chance of actually changing social beliefs, but also because it assumes that individuals who belong to white supremacist groups are not necessarily white supremacist.

Niebuhr would appear to look at black/white relations as a kind of social division-groups are segregated into communities of class, education, wealth, and location. Would members of black communities have a similar experience of black/ white relations or are they more likely to experience a social rift—an alienation between the two social worlds. During the time of the white compromise, when lynchings and race riots were occurring under the white man's nose, whose experience would give us a better understanding of the social relationship between whites and blacks? Should the white man's experience determine the strategy for change? One answer to this question was given by Martin Luther King Jr. In his famous "Letter from Birmingham Jail," King responds to those who have advised him to go slower and give more time for whites to adjust to an integrated society. In the letter, King answers those who found his actions "unwise and untimely," by arguing that there is no "right" time to bring about the necessary change. He writes:

We know though painful experience that freedom is never voluntarily given by the oppressor; it must be demanded by the oppressed (1964, p. 88).

As Taylor Branch points out in his biography of King, during his graduate studies at Boston University, he had wrestled with and was greatly influenced by Niebuhr's realism (1988, p. 87). In the letter just quoted, King acknowledges what he has learned from Niebuhr:

Lamentably, it is an historical fact that privileged groups seldom give up their privileges voluntarily. Individuals may see the moral light and voluntarily give up their unjust power; but, as Reinhold Niebuhr has reminded us, groups tend to be more immoral than individuals (p. 80).

Still, Niebuhr's remarks about non-violence were written during the time of the white compromise, and King's remarks were written as it was being destroyed. They probably agreed on the tactic of non-violence more than they disagreed, although Niebuhr emphasized its function in not triggering the hostility of white individuals, while King emphasized its function in the empowerment of black communities. King saw this empowerment through the union of power and love, which he eloquently expressed in his 1967 speech at the Southern Christian Leadership Conference:

Now we got to get this thing right. What is needed is a realization that power without love is reckless and abusive, and that love without power is sentimental and anemic. Power at its best is love implementing the demands of justice, and justice at its best is love correcting everything that stands against love. And this is what we must see as we move-on (2015, p. 172).

We want to get this thing right as well. Do we limit our actions for change by the degree of discomfort those in power can tolerate or do we limit our actions by what is 
necessary to empower the powerless? How do we balance these two goals? We will see Niebuhr's answer later. For now, we will follow the trajectory of Niebuhr's career in the 1940s, and 1950s, as he turned his attention to the pressing issues of foreign policy.

\subsection{Niebuhr on American Power in the World}

Niebuhr didn't return to the issue of race relations until the 1954 Supreme Court ruling outlawing segregation in the public schools. From the late $30 \mathrm{~s}$ to the $1950 \mathrm{~s}$, the rise of Nazism, Soviet Communism, World War II and the Cold War brought difficult questions about the development of suitable relationships with other powers. Niebuhr addressed such issues and established himself as a leading American thinker. In 1952, Niebuhr suffered a stroke that paralyzed his left side and impaired his speech, but that did not halt his continued influence in American thought. We will consider only two of his multiple works during this period: The Children of Light and the Children of Darkness and the book The Irony of American History.

\subsubsection{Children of Light and Children of Darkness}

Niebuhr's 1944 book on the differences between the "children of light" and the "children of darkness," contrary to what you might expect, focuses more on the problems of the children of light — the good guys - than on the children of darkness. For Niebuhr, evil is not that difficult to understand; the difficulty is with the limits of goodness. The challenge of the children of light is that they tend not to take seriously enough the children of darkness nor to comprehend their own darkness.

Since the survival impulse in nature is transmuted into two different and contradictory spiritualized forms, which we may briefly designate as the will-to-live-truly and the willto-power, man is at variance with himself... . The fact that the will-to-power inevitably justifies itself in terms of the morally more acceptable will to realize man's true nature means that the egoistic corruption of universal ideals is a much more persistent fact in human conduct than any moralistic creed is inclined to admit (1944. p. 21).

Darkness and Light, in other words, are inseparable. Still, they are also different. The light needs just as much attention as the darkness. Recognizing this complexity of human action provides "A Vindication of Democracy and A Critique of its Traditional Defense, which is the book's subtitle. The traditional vindication relies on the liberal notion of freedom, which Niebuhr criticizes as naïve in its understanding of power. His vindication of democracy, on the other hand, is that it checks power with power, and that it affirms both man's will-to-live truly and man's will-to-power. Or, as Niebuhr says: 
Man's capacity for justice makes democracy possible; but man's inclination to injustice makes democracy necessary (p. xi).

The virtue of democracy for Niebuhr was not that everyone was equally represented so much as it could mediate between divergent powers within groups and balance the power between conflicting groups.

The preservation of a democratic civilization requires the wisdom of the serpent and the harmlessness of the dove. The children of light must be armed with the wisdom of the children of darkness but remain free from their malice. They must know the power of selfinterest in human society without giving it moral justification (pp. 40-41).

It may seem like Niebuhr has a rather static view of groups, an inherent tension between darkness and light within as well as without. Groups are trapped in their hunger for power and the best one can do is to restrict their impulses. One might think that Niebuhr believed that groups cannot escape the tendency to think of themselves as more perfect than they are-to be pretentious-but that is not the end of the story. Niebuhr provides something of a step-by-step process for dealing with pretensions in his book on the irony of American history.

\subsubsection{The Irony of American History}

Niebuhr begins and ends this book with a description of irony, which he presents as a process of exposure, recognition, and response. These are not Niebuhr's words, but I think they describe his proposed sequence, which includes the following steps:

1. One of life's incongruities appears

2. When examined, one uncovers a relationship in the incongruity;

3. The person involved becomes conscious of the relationship;

4. The irony is dissolved either through contrition or "a desperate accentuation of the vanities to the point where irony turns into pure evil" (2008, p. viii)

As Niebuhr makes clear in the book's final chapter, this view of irony matches his understanding of the Christian faith. "Yet the Christian faith tends to make the ironic view of human evil in history the normative one" (p. 155). In fact, irony is almost inevitable when one accepts Niebuhr's dualistic view of human nature: humans are both creators and creatures of history. If you accept this theory, then you have a formula that can be applied to multiple situations.

One could apply this ironical interpretation, for example, to Niebuhr's experience in Detroit with black and white individuals and groups. The incongruity would be the white pretension of superiority over others. When this incongruity is exposed, people have a choice of contrition or as Niebuhr says, an "accentuation of the vanities." Perhaps he witnessed contrition by some white people on the inter-racial commission he chaired. He probably also witnessed, especially with the rise of the KKK, "pure evil." Niebuhr doesn't use such experiences to illustrate his theory. In fact, this book on the irony of American history totally ignores the history of black/ white relations. What could be more ironic than that? 
The book was published in 1952, at the time of the Cold War between the Soviet Union and the United States. Although Niebuhr attacked communism for its hypocrisy, he seems more worried that the United States would exaggerate its capacity for doing good, because it had little experience in global conflicts. Niebuhr describes the image of the nation, drawn from the ideas of the Puritans and Thomas Jefferson as a nation beginning something new, without the baggage of European history.

We were not only innocent a half century ago with the innocence of responsibility; but we had a religious version of our national destiny which interpreted the meaning of our nationhood as God's effort to make a new beginning in the history of mankind (p. 4).

Niebuhr sees this image of the new beginning as somewhat pretentious. His point, however, is not to expose the incongruity between the official story of the nation's beginning and its actual beginning (slavery and confiscation of land), but rather to focus on the incongruity of a nation that sees itself as a new beginning and its current role as a global power with the responsibility to avoid total war. Exposing this irony, if I read Niebuhr correctly here, opens the options for the nation of either becoming contrite or defending its pretentions. Niebuhr's concern over the danger of the nation losing any awareness of its complicated relationship with its own power leads him to write:

Nations, as individuals, who are completely innocent in their own esteem, are insufferable in their human contacts (p. 42).

One could imagine, perhaps wish, that Niebuhr had applied this insight to the white compromise, but in this book, Niebuhr's story of American history does not include African Americans or Native Americans. Perhaps the ultimate irony of this book on irony is that it ignores the incongruity between white American history and the complete history of America. His story, in other words, is incoherent.

The principle of coherence says that if you cannot understand A without understanding $\mathrm{B}$, then you cannot understand $\mathrm{B}$ without understanding $\mathrm{A}$. Or in this case: "If you cannot understand black America without understanding white America, then you cannot understand white America without understand black America." In this book, Niebuhr writes as though one could isolate white America from non-white America, which was a basic tenant of the white compromise. At this stage in Niebuhr's life, it seems to be in full force.

In Niebuhr's biography in the 1963 Encyclopedia Britannica, his Union colleague, John Bennett, quotes Hans J. Morgenthau's naming Niebuhr "the greatest living political philosopher of America" (2017). At the same time Bennett does not write one word about Niebuhr's contributions to understanding racial pride and white supremacy. Not only Niebuhr's work, but also interpretations of his work, seemed to be by and for whites only. At the peak of his national influence, whatever he learned from the years in Detroit working with black and white groups was not something he referred to in his political writing. Niebuhr did address the issue of race relations in a couple of short articles about the 1954 Brown v Board of Education Supreme Court decision, which struck down the "separate but equal" ruling. 


\subsection{Niebuhr and Race in the 1950s}

Although Niebuhr supported the Court's ruling, his primary worry seems to have been that those who saw it as a victory for civil rights would not recognize their own group pride, and even worse, would not have enough sympathy for those white families who disagree with the ruling. In an article written in 1956, Niebuhr cautions against pushing white parents too fast to adjust to black and white children attending the same schools (Kisshauer 2015). Some have taken his remarks as supporting a more incremental approach to racial issues, but as Gideon Mailer points out in his recent essay on Niebuhr and race, Niebuhr actually argued that legal actions could help in changing customs, and that changing customs take time (2015). According to Therese B. DeLasio, when Niebuhr noticed the lack of progress in the integration of schools, he became more critical of white groups, especially white churches (2008). Still, his cautiousness about creating negative backlash reminds me of the earlier analysis of his pragmatic approach to non-violent action.

So how should one understand the relationship between Niebuhr's early experiences in Detroit and Mississippi and his later response to the integration of public schools? Perhaps the racial bigotry he experienced in Detroit influenced his theological analysis of human nature in his first years at Union. He then used this theological framework to interpret the limits of group morality and the need to keep in check any group's power, which served as the foundation for his Christian Realism. It seems that Niebuhr used this perspective to interpret such events as the World Wars and the rise of Communism, and then applied this cautionary approach to race relations in the $1950 \mathrm{~s}$.

In Detroit, Niebuhr certainly recognized the suffering and misery of black groups and the "racial pride" of white groups, but he didn't give enough recognition to the relationship between these groups, or how their social identity depended on each other. He seems to see groups as isolated entities, just as he sees individuals as isolated entities. The reason for this may be grounded in his dualistic protestant theology.

\subsection{Niebuhr's Dualism}

A key principle in Niebuhr's theology is that man (sic) is created in the image of God. In Protestant monotheism, this can easily imply that since God is one, whatever God creates is also one. One God equals one man, or one group-a collective one. An alternative view of Christian theology sees three gods, or three-in-one, which is the more orthodox trinitarian view of Father, Son and Spirit. The theologian Paul Lehmann thinks that Niebuhr's theology does not pay enough attention to the third part of the trinity; the Holy Spirit, which refers to the potential for the creation of a loving community (1956). Without this possibility for creating new communities, groups that are estranged from one another can only try to improve themselves, but 
not the broken relationships that could re-unite them. This possibility for the creation of community between opposing and conflicting groups does not seem to get much attention in Niebuhr's thinking.

Niebuhr's participation in the Delta Cooperative indicates that he did know about the creation of community, and perhaps even something about the relationship between community and land, but none of this is explicitly stated in his later social ethics. Niebuhr does use the word "community" in his final book: Man's Nature and His Communities (1965), which appeared eleven years after the Brown v Board of Education decision and 10 years after Rosa Parks refused to go to the back of the bus. In the early 1960s the freedom riders, the Birmingham boycott, the march on Washington, the leadership of Martin Luther King Jr., the 1964 Civil Rights Act, as well as other events, had so ruptured the white compromise that it no longer held sway over the nation. So, Niebuhr's final book was written in a different world. Before we look at this book, I want to conclude my interpretation of Niebuhr in the time of the white compromise.

\subsection{Niebuhr and the White Compromise}

In his profound and challenging book, The Cross and the Lynching Tree, James Cone asks the following question about Niebuhr's years at Union Theological Seminary:

Why did Niebuhr fail to connect Jesus's cross to the most obvious cross bearers [those lynched] in American society? (2011, p. 132).

This is not only a disturbing question for our understanding of Niebuhr's work, but also, for some of us, for understanding our own work. Even though the civil rights movement destroyed the staying power of the white compromise, it has not-not at all-been replaced by a new agreement among all of us. The development of Niebuhr's career is not so different from the career development of many others.

As I have presented Niebuhr's experiences and ideas, he seems to have both accepted and rejected the white compromise. He clearly rejected the widespread agreement to not bring black and white people together to talk about their relationship, especially in Detroit and in his participation in the Delta Cooperative Farm in Mississippi. These practices, however, were not what made him famous or admired. In fact, his fame was largely based on his thinking and writing that had nothing to do with race. In a sense Niebuhr's fame demonstrates the success of the white compromise- to think and write as though America was white America.

How did Niebuhr accept the white compromise? First of all, his stories of what I would call "Atlantic history" included only Europe and European/Americans and excluded Africans and Native Americans. In his book, Children of Light and Children of Darkness, he writes of Adam Smith as one who belongs to the "Children of Light" because Smith believed that self-interest was subordinate to a larger good. Niebuhr appears not to know, or at least not to acknowledge, that Smith's world was 
dependent on the Atlantic trade of enslaved people. In fact, Niebuhr never sees American history as a history of multiple peoples, but only of white people, as though people of color did not exist.

In his book on the irony of American history, he writes that Americans represented a new beginning separated from European, but he doesn't say that the United States continued using enslaved people long after the British outlawed it. Furthermore, he assumes an innocence of European Americans and an American optimism that actually rests on the appropriation of the land of Native Americans and the enslavement of millions of Africans. Until the Civil War, the United States was a slave nation, not that much unlike Saint Domingue before the Haitian Revolution. Unlike the Haitian revolution that ended the enslavement of people, the American Revolution protected it.

Niebuhr does not question, and may actually reinforce, what had become a key myth of the compromise: America's prosperity was the result of hard work and good fortune. He believed that the danger here was hubris, not deception. What is missing from his focus on pride is any recognition that some groups have greatly benefited from the exploitation and domination of other groups. Most of his work appears to assume that groups, like individuals, are isolated units existing in their own world rather than in a common world. He addresses this issue in his final book on human communities.

\subsection{Niebuhr and the Human Community}

In Man's Nature and His Communities, Niebuhr shares some of the changes he had made in his thinking. A good sign of the change can be seen in the difference between his early terminology of "moral man and immoral society," and this book's title of "Man's Nature and His Communities." Does this change represent a different view of human groups? It's not entirely clear. The doctrine behind the notion of immoral society was original sin. In the introduction to this volume, Niebuhr shares that he learned that stressing this theological concept was "anathema to modern culture" (1965, p. 23 In this book, he uses different terminologies, including the terminology of tribalism and a common humanity. With this terminology Niebuhr writes:

The difficulties America has experienced in acknowledging the common humanity with a racial minority marked by observable racial identification of dark color and by historically caused cultural backwardness to give a vivid example of the basic paradox of man's inhumanity to man. This paradox consists, on the one hand, in the obvious unity and common humanity of men, derived from their rational freedom over nature and the indeterminate creative possibilities of that freedom, which distinguishes them from other animals and constitutes the human race as one single species. It consists, on the other hand, in the fact that this supposedly rational creature is able to recognize a common humanity only in the uncommon and unique marks of a tribal "we group," or more recently, "national"communities in which the dignity of man is expected and rights are acknowledge and enforced; while others, lacking these obvious marks of tribal identity, whether racial, 
linguistic, cultural, or religious, are treated brutally as if they were not part of a common human race (pp. 90-91).

Niebuhr concludes here with a hopeful note that since this paradox had become a "national interest" it might be resolved but it may take "at least a century." Still, he provides some hope that in fact, our differences are not natural, but social which could mean that they can be changed.

No one could deny that the cultural and moral differences between groups and nations are real. But only time and experience will prove that they are not innate, and that in any case,

they cannot reasonably deny a common humanity to all men (p. 95).

Niebuhr is not saying that this "common humanity is just another term for original sin; rather, he means it as a reference to human dignity. This does not mean that Niebuhr believes that an awareness of our common humanity is easy to achieve, but nor does he say it is totally beyond our grasp.

In this book's final essay, Niebuhr explores the paradoxical nature of humans as self-seeking and self-giving. In his view, the paradox is that a total focus on selfseeking doesn't bring one self-fulfillment but self-giving does. The reason for the paradox is "the social substance of human existence" (p. 107). This looks quite different from Niebuhr's early contrast between moral man and immoral society. Instead of treating society as collectives that inhibit or even prevent individual moral action, Niebuhr sees community more as the basis for such action. As he writes: "This is true because the self needs other selves in order to be itself. This is the nature of the self, and also its destiny" (p. 112). On the other hand, it would be a mistake to say that Niebuhr has abandoned his dualistic thinking-it is now between selfseeking and self-giving. Still, he appears to have grounded his dualism in social relations rather than in natural impulses. This will make a difference in exploring the relationship between Niebuhr's work and the four strands of American prosperity-treating land as a commodity, racializing humanity, maintaining social incoherence, and a militarized civic.

\subsection{Niebuhr and American Prosperity}

Niebuhr's Christian Realism was a direct challenge to the American Prosperity language of manifest destiny, the widely held view that Western expansion was part of God's plan for Christian Anglo-Saxons. Still, as a descendant of settler immigrants, he didn't appear to challenge the dominant view of land as a commodity. On the other hand, I don't think he believed in a racialized humanity. He focused on social differences rather than human differences At the same time, he appears to have overlooked the need to repair the broken relationships among different groups before they could actually share a common humanity.

Niebuhr was certainly aware of the social groups and the misery of black communities... His early involvement in the empowerment of sharecroppers illustrates his concern for the poor, but not so much for how they got poor. For the most 
part, he focused on the nature of groups rather than on their relationships with each other. Still, we should not forget his reflections on the complexity of human action, nor his call for the powerful to embrace humility.

The fourth element of American prosperity a militarized civic, received Niebuhr's strongest criticism. His theory of containment, which argued for the recognition of limits in international relations, called for a balance of military forces. With hindsight, we can say today that the theory of containment could not create a climate of justice because it failed to take seriously the violations of humanity that were part and. parcel of American prosperity. The white compromise held its sway in allowing white men, including Niebuhr, to live in the illusion that there was an America without people of color.

Niebuhr did address some aspects of dangers of American prosperity, especially its racialized humanity and the military civic. The part of the American prosperity he considered the least, and that now our planetary crisis has made a necessity, is the treatment of land as a commodity. Until we re-think our relationship with the Earth, I doubt if we will be able to save it as a human habitat.

\section{References}

Alperovitz, G. 2013. What Then Must We Do: Straight Talk about the Next American Revolution. White River Junction: Chelsea Green Publishing.

Bates, B.T. 2014. The Making of Detroit of Henry Ford. Chapel Hill: The University of North Carolina Press.

Bennett, J.C. 2017. Reinhold Niebuhr Encyclopedia Britannica. Encyclopedia. Britannica Online, Encyclopedia Britannica Inc. https://www.britannica.com/biography/Reinhold-Niebuhr.

Branch, T. 1988. Parting The Waters: America in The King Years 1954-1963. New York: A Touchstone Book.

Brooks, D 2007. Obama, Gospel and Verse. .The New York Times. April 26. http://select.nytimes. com/2007/04/26/opinion/26brooks.html?_r=1.

Cone, J.H. 2011. The Cross-and the Lynching Tree. Maryknoll: Orbis Books.

DeLisio, T.B. 2008. Did Reinhold Niebuhr Care About Race in America. Union Seminary Quarterly Review 61 (3-4): 1-16.

Dyer Anti-Lynching Bill 1922. https://www.naacp.org/naacp-history-dyer-anti-lynching-bill/.

Foner, E. 2002. Reconstruction: America's Unfinished Business 1863-1877. New York: Perennial Classics.

Fox, R.W. 1996. Reinhold Niebuhr: A Biography. Ithaca/London: Cornell University Press.

Kester, H. 1997. Revolt Among The Sharecroppers. Knoxville: The University of Tennessee Press.

King, M.L. 1964. Letter from Birmingham Jail. In Why We Can't Wait. New York: A Mentor Book New American Library.

- 2015. Where Do We Go From Here? In The Radical King: Martin Luther King, Jr., ed. Cornel West. Boston: Beacon Press.

Kisshauer, C. 2015. Reinhold Niebuhr: His Perspective on Desegregation as Influenced by Christian Realism. http://www.belmont.edu/burs/pdf/History\%20-\%20Kisshauer\%20-\%202015.pdf. 
Lehmann, P. 1956. The Christology of Reinhold Niebuhr. In Reinhold Niebuhr: His Religious, Social, and Political Thought, ed. C.W. Kegley and R.W. Bretall. New York: The Macmillan Company.

Mailer, G. 2015. Not eradicated by enlightenment alone,: Reinhold Niebuhr and the conflicted meaning of racial factions in American life. 49" Parallel, Issue 35. http:// 49thparalleljournal.org.

McWhirter, C. 2011. Red Summer: The Summer of 1919 and The Awakening of Black America. New York: Henry Holt and Company.

PBS. 2017. An American Conscience: The Reinhold Niebuhr Story. http://www.pbs.org/video/ 2365984011/.

Niebuhr, R. 1941. The Nature and Destiny of Man: A Christian Interpretation. New York: Charles Scribner's Sons.

1944. The Children of Light and the Children of Darkness: A Vindication of Democracy and a critique of its traditional defense. New York: Charles Scribner's Sons.

. 1945. Christian Faith and the Race Problem. Christianity and Society. Vol. 10, Spring. in Reinhold Niebuhr on Politics: His Political Philosophy and Its Application to Our Age as Expressed in His Writings ed. Davis, D. R. and Good, R.C. New York: Charles Scribner's Sons, 1960, 233.

- 1957. Leaves From the Notebook of a Tamed Cynic. Louisville: Westminster/John Knox Press.

- 1960. Moral Man and Immoral Society. New York: Charles Scribner's Sons.

1965. Man's Nature and His Communities: Essays on the dynamics and enigmas of man's personal and social existence. New York: Charles Scribner's Sons.

- 1997. Forward. In Revolt Among The Sharecroppers, ed. H. Kester. Knoxville: The University of Tennessee Press.

- 2008. The Irony of American History. New York: Charles Scribner's Sons.

S.Res. 39(109th) 2005. Lynching Victims Senate Apology resolution. https:/www.govtrack.us/ congress/bills/109/sres39/text.

Wells-Barnett, I. 1920. The Arkansas Race Riot. Chicago: Ida B. Wells-Barnett.

Wilkerson, I. 2011. The Warmth of Other Suns: The Epic Story of America's Great Migration. New York: Vintage Books, A Division of Random House, Inc.

Woodruff, N.E. 2003. American Congo: The African American Freedom Struggle in the Delta. Chapel Hill: The University of North Carolina Press.

Open Access This chapter is licensed under the terms of the Creative Commons Attribution 4.0 International License (http://creativecommons.org/licenses/by/4.0/), which permits use, sharing, adaptation, distribution and reproduction in any medium or format, as long as you give appropriate credit to the original author(s) and the source, provide a link to the Creative Commons license and indicate if changes were made.

The images or other third party material in this chapter are included in the chapter's Creative Commons license, unless indicated otherwise in a credit line to the material. If material is not included in the chapter's Creative Commons license and your intended use is not permitted by statutory regulation or exceeds the permitted use, you will need to obtain permission directly from the copyright holder.

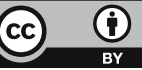

